\title{
FORMULASI STRATEGI PENGEMBANGAN DIGITAL BANKING (STUDI KASUS BANK ABC)
}

\author{
STRATEGIC FORMULATION OF THE DIGITAL BANKING DEVELOPMENT \\ (CASE STUDY OF BANK ABC)
}

\author{
Haris Budiman*1, Kudang Boro Seminar**), dan Imam Teguh Saptono*) \\ *) Sekolah Bisnis, IPB University \\ Jl. Raya Pajajaran, Bogor 16151, Indonesia \\ **) Fakultas Teknologi Pertanian, IPB University \\ Kampus IPB Dramaga, Bogor 16680, Indonesia
}

\begin{abstract}
Threat to banking industries, other than Fintech in sector of payment such as the GoPay, threat is also come out of Fintech and Startup in sector of loan such as the UangTeman. Revolution in digital technology produced by the Fintech and the Startup changes people's behavior to access financial services, from coming to bank office to be an access in using smart phone. Objectives and research methods use qualitative and quantitative approaches as follows: to identify existing core competencies of the Bank $A B C$ using the VRIO (Valuable, Rare, Inimitable, Organized to Capture Value) and recommendation of future competencies using the industry foresight; to formulate and to look into strategic alternative using the Porter's Five Force, the Internal-External matrix, the SWOT matrix, and the QSPM; to recommend road maps to strategic implementation of the digital banking using the AHP. Research results recommend 3 future competencies that the Bank $A B C$ needs to have in the digital banking development from development of 13 existing core competencies by implication in competitive advantage. The main strategic alternative for calculation result of the AHP is reengineering bank products that are able to be marketed by the Bank ABC or the Fintech and the Startup. Based on calculation of the AHP, the main future competency is the Two-Way Digitalization.
\end{abstract}

Keywords: core competency, digital banking, digital technology, fintech, industry foresight

\begin{abstract}
Abstrak: Ancaman terhadap industri perbankan, selain datang dari Fintech (financial technology) bidang pembayaran seperti GoPay, ancaman juga muncul dari Fintech dan Startup bidang pinjaman seperti UangTeman. Revolusi teknologi digital yang dibawa oleh Fintech dan Startup mengubah perilaku masyarakat dalam mengakses jasa keuangan, dari datang ke kantor bank, menjadi akses menggunakan telepon pintar. Tujuan dan metode penelitian menggunakan pendekatan kualitatif dan kuantitatif sebagai berikut: mengidentifikasi kompetensi inti eksisting Bank ABC menggunakan VRIO (Valuable, Rare, Inimitable, Organized to Capture Value) dan rekomendasi kompetensi masa depan menggunakan industry foresight; untuk merumuskan dan mengkaji alternatif strategi menggunakan Porter's Five Force, matriks Internal-External, matriks SWOT, dan QSPM; untuk merekomendasikan road map implementasi strategi perbankan digital menggunakan AHP. Hasil penelitian merekomendasikan 3 kompetensi masa depan untuk dimiliki Bank $\mathrm{ABC}$ dalam pengembangan perbankan digital dari pengembangan 13 kompetensi inti eksisting dengan implikasi keunggulan kompetitif. Alternatif strategi utama hasil perhitungan AHP adalah reengineering produk bank yang dapat dipasarkan baik oleh Bank ABC maupun Fintech dan Startup. Berdasarkan perhitungan AHP, kompetensi masa depan utama adalah Digitalisasi Dua Arah.
\end{abstract}

Kata kunci: kompetensi inti, perbankan digital, teknologi digital, fintech, industry foresight

\footnotetext{
${ }^{1}$ Corresponding author:

Email: budiman.haris@gmail.com
} 


\section{PENDAHULUAN}

Menurut survei Jakpat dalam riset Startup Report 2017 yang dirilis DailySocial.id, Go-Pay dari GoJek merupakan uang elektronik terpopuler dan paling banyak dimiliki oleh publik. Go-Pay mengalahkan uang elektronik yang diterbitkan oleh perbankan, seperti e-money dari Bank Mandiri dan Flazz dari BCA. Sebanyak 50 persen responden mempunyai uang elektronik keluaran perusahaan penyedia jasa layanan transportasi online Go-Jek. Sementara e-money (Bank Mandiri) berada di urutan kedua dan t-cash (Telkomsel) ketiga.

Ancaman pada industri perbankan, selain dari Fintech (financial technology) Payment, ancaman muncul juga dari perusahaan pemula (Startup) dan Fintech Lending. Pemerintah dan Bank Indonesia (BI) menargetkan tingkat inklusi keuangan meningkat menjadi $75 \%$ pada tahun 2019, dan upaya peningkatan itu diantaranya dilakukan melalui bantuan Fintech. Otoritas Jasa Keuangan (OJK) mengeluarkan Peraturan OJK (POJK) Nomor 77/POJK.01/2016 tentang Layanan Pinjam Meminjam Uang Berbasis Teknologi Informasi untuk Fintech yang berbisnis pinjaman online. Startup dan Fintech didukung oleh pemerintah dengan dikeluarkannya Peraturan Presiden Republik Indonesia Nomor 74 tahun 2017 tentang Peta Jalan Sistem Perdagangan Nasional Berbasis Elektronik (Road Map E-Commerce) tahun 2017-2019. Salah satu kegiatan dalam road map tersebut adalah meningkatkan akses Kredit Usaha Rakyat (KUR) melalui Bank/Industri Keuangan Non-Bank sebagai penyalur KUR dengan penilaian risiko kredit yang disesuaikan dengan model bisnis perdagangan berbasis elektronik (e-commerce).

Revolusi teknologi digital mengubah perilaku pelanggan/ nasabah, pelanggan dan transaksi di cabang Bank $\mathrm{ABC}$ sudah jauh berkurang. Interaksi nasabah dengan Bank $\mathrm{ABC}$ sudah mulai beralih dari datang ke Kantor Cabang menjadi melalui media digital kapanpun dan dimanapun. Transaksi melalui cabang (branch) Bank $\mathrm{ABC}$ adalah 4 kali lebih kecil dibandingkan dengan transaksi electronic channel (e-channel). Bank ABC adalah pemimpin pasar dalam bisnis pembayaran public utilities (pulsa, token listrik, paket data, multifinance, dan sebagainya) melalui loket, akan tetapi mulai terdisrupsi oleh e-commerce yang menjalankan bisnis pembayaran public utilities dengan biaya yang lebih murah dan tanpa harus datang ke loket. Penurunan tajam transaksi public utilites sebesar $72 \%$ melalui loket terjadi pada bulan Juli
2017. Sejak melakukan kerjasama dengan Fintech dan E-Commerce (non loket), meskipun belum kembali ke posisi bulan Juni 2017, transaksi meningkat sejak bulan Oktober 2017 sampai dengan 55\% pada bulan Januari 2018. Pada penelitian Singh (2004) terkait masa depan dari perbankan, konsumen perbankan mengharapkan kemudahan terkait tempat, proses dan waktu dalam bertransaksi. Menurut Mbama dan Ozepue (2018), dalam digital banking, customer experience merupakan hal penting dalam meningkatkan performa dan perbaikan mutu dalam implementasi bisnis.

Berdasarkan penelitian Wonglimpiyarat (2017), implikasi mendalam pada sifat sistemik dari inovasi memberikan tren dan arah pengembangan inovasi berbasis Fintech di industri perbankan. Menurut Maiya (2017), digitalisasi selektif dan dangkal tidak akan membantu bank konvensional untuk menyesuaikan dengan harapan tinggi pelanggan yang melek digital saat ini atau mengatasi tantangan yang semakin meningkat dari inovator-inovator Fintech yang dicapai secara digital. Bank membutuhkan strategi holistik dan sistematis untuk menata kembali dan menemukan kembali bisnis mereka di sekitar kompetensi teknologi digital untuk muncul sebagai entitas digital yang sesungguhnya. Semakin kompleks kompetensi yang mengarah ke keunggulan kompetitif, dalam hal kumpulan sumber daya yang perusahaan integrasikan, semakin sulit bagi pesaing untuk menyalinnya, memungkinkan keunggulan kompetitif dipertahankan untuk jangka waktu yang lebih lama (Cardeal dan Antonio 2012). Perbankan harus menyiapkan formula strategi bisnis untuk dapat bersaing dengan bank lainnya (Cortet et al. 2016). Skartiningron (2017), Agustina (2018) dan Indira (2018) melakukan penelitian perbankan digital di Indonesia tetapi belum ada penelitian yang menghasilkan strategi pengembangan perbankan digital dengan sasaran kompetensi masa depan pendukungnya.

Dalam rangka menghadapi persaingan baru dan perubahan perilaku pelanggan dikarenakan teknologi digital, Bank $\mathrm{ABC}$ harus mulai untuk mengatur kembali posisi pada rantai bisnis. Hal ini berguna untuk menjaga aktifitas bisnis perbankan Bank ABC di masa depan. Penelitian ini bertujuan untuk: (1) mengidentifikasi kompetensi inti Bank ABC pada saat ini dan kompetensi apa yang sebaiknya dikembangkan oleh Bank ABC di masa yang akan datang dalam upaya mengembangkan digital banking; (2) merumuskan dan mengkaji alternatif strategi yang berkelanjutan dalam mengembangkan digital banking Bank ABC; (3) merekomendasikan road map implementasi strategi digital banking Bank ABC. 


\section{METODE PENELITIAN}

Penelitian ini menggunakan pendekatan deskriptif dalam bentuk studi kasus pada strategi pengembangan digital banking Bank ABC. Penelitian dilakukan di kantor pusat Bank ABC yang berlokasi di Jakarta pada bulan Juni 2018 sampai dengan bulan September 2018. Metode penelitian menggunakan pendekatan kualitatif dan kuantitatif. Pendekatan kualitatif dengan metode deskriptif dilakukan melalui pengamatan langsung dan wawancara untuk memperoleh data, fakta dan faktor strategis internal dan eksternal serta kompetensi inti dan kompetensi masa depan dalam menghadapi digital banking. Faktor-faktorstrategis yang diperoleh darihasil pengamatan langsung dan wawancara serta didukung studi pustaka yang relevan akan digunakan sebagai sumber kuesioner. Pendekatan kuantitatif dilakukan dengan pembobotan dan penilaian terhadap hasil pengisian kuesioner. Formulasi strategi menggunakan pendekatan David (2011) dalam rangka menentukan strategi yang tepat bagi organisasi. Tahapan dalam penelitian ini dapat dilihat pada Gambar 1.

Pada penelitian ini digunakan dua jenis data yaitu primer dan sekunder. Data primer diperoleh melalui pengamatan langsung, wawancara dan pengisian kuesioner, sedangkan data sekunder berasal dari dokumen-dokumen perusahaan, rujukan yang mendukung dan studi kepustakaan. Penentuan responden dilakukan dengan menggunakan teknik purposive sampling. Pengambilan contoh dilakukan dengan indepth interview. Melalui pendekatan yang sederhana, manajer dan karyawan dapat meningkatkan persepsi dan pemahaman mengenai kondisi perusahaan saat ini (Ramadhani et al. 2018). Responden pada penelitian ini adalah Direktur Bisnis Konsumer, Direktur Operasi, General Manager TI, Manajer Strategi TI, Manajer Tata Kelola Digital, Manajer Produk Digital \& Transaksi, Manajer Operasi Digital $\&$ Transaksi, dan Manajer Pemasaran.

Analisis sasaran Bank ABC adalah tahap awal dan acuan dalam melakukan tahapan penelitian berikutnya. Analisis VRIO digunakan untuk mengetahui lingkungan internal perusahaan. Dalam sebuah industri ada perusahaan yang lebih unggul, menjadi leader dibanding perusahaan lain padahal semua menghadapi lingkungan eksternal yang sama, maka dapat disimpulkan bahwa lingkungan internal adalah pembeda satu perusahaan dengan perusahaan lain (Wandrial, 2011). Analisis Porter's Five Force digunakan untuk mengetahui lingkungan eksternal perusahaan. Candra (2013) dalam penelitiannya menggunakan Porter's Five Force untuk melihat persaingan perusahaan pada satu industri.

Untuk mengetahui faktor kekuatan dan kelemahan internal digunakan analisis IFE. Faktor peluang dan ancaman perusahaan dianalisis menggunakan EFE. Selanjutnya tahapan pencocokan dari hasil identifikasi dan pembobotan menggunakan matriks InternalExternal (IE) untuk mengetahui posisi perusahaan yang sebenarnya sebelum melakukan penentuan strategi terbaiknya. Menurut Raymond et al. (2012) matriks IE merupakan alat perumusan strategi meringkas dan mengevaluasi kekuatan dan kelemahan utama dalam area fungsional bisnis, dan juga menjadi landasan untuk mengidentifikasi serta mengevaluasi hubungan di antara area tersebut.

VRIO juga digunakan untuk identifikasi kompetensi inti Bank ABC. Menurut penelitian Agha et al. (2012), kompetensi inti adalah sekelompok pengetahuan yang dimiliki perusahaan yang membedakan perusahaan tersebut, dan menciptakan keunggulan bersaing terhadap para kompetitornya. Hasil identifikasi kompetensi inti Bank ABC dievaluasi dalam menghadapi perbankan digital, oleh karena itu digunakan analisis industry foresight untuk merekomendasikan kompetensi masa depan Bank ABC. Berdasarkan penelitian Tornjanski et al. (2015), berkenaan dengan perspektif holistik tentang manajemen inovasi di perbankan, kerangka kerja yang memperhitungkan tujuh perspektif: proses inovasi yang dikelola, penyelarasan strategis, industry foresight, wawasan pelanggan, teknologi dan kompetensi inti, kesiapan organisasi, dan penerapan disiplin, mengarah ke manajemen inovasi yang sistematis, yang mewakili landasan untuk menciptakan inovasi radikal sebagai dasar untuk pengembangan kinerja bisnis.

Alternatif strategi yang cocok dilakukan berdasarkan hasil matriks IE dan SWOT antara lain adalah penetrasi pasar, pengembangan pasar, pengembangan produk, integrasi ke depan, integrasi menyamping, dan integrasi ke belakang (Hage et al. 2015). Penelitian implementasi teknologi finansial dengan menggunakan pendekatan SWOT terbukti memberikan gambaran mengenai kondisi penerapan teknologi finansial saat ini, namun pengunaan SWOT belum dapat memberikan decision mengenai strategi lanjutannya (Chrismastianto, 2017). Pada penelitian Ommani (2011) mengunakan SWOT dan QSPM, QSPM dianggap mampu memberikan 
rumusan yang tepat untuk implementasi strategi. Sementara Mahfud dan Mulyani (2017) menjelaskan bahwa SWOT dengan dibantu matriks IE dapat memberikan gambaran yang tepat dalam menentukan posisi perusahaan, selain itu QSPM mampu memberikan gambaran untuk memutuskan strategi yang tepat untuk objek. QSPM (Quantitative Strategic Planning Matrix) adalah alat yang direkomendasikan untuk melakukan evaluasi pilihan strategi alternatif secara objektif berdasarkan faktor kunci sukses internal eksternal.

Dalam penyusunan road map strategi dan untuk menggambarkan keterhubungan antara sasaran Bank ABC dengan kompetensi masa depan dan alternatif strategi, digunakan metode AHP (Analytic Hierarchy Process). AHP memiliki banyak keunggulan dalam menjelaskan proses pengambilan keputusan karena dapat digambarkan secara grafis, sehingga mudah dipahami oleh semua pihak yang terlibat dalam pengambilan keputusan tersebut (Budiarto et al. 2018). Sasaran Bank ABC akan dipilih sebagai elemen goal atau tingkat puncak dalam hierarki disusul kompetensi masa depan dan alternatif strategi.

Dari hasil identifikasi kompetensi inti eksisting Bank ABC menggunakan VRIO dan analisis industry foresight tren teknologi digital perbankan dan Fintech diharapkan dapat menjawab pertanyaan kompetensi masa depan apa yang harus dikembangkan atau diakusisi oleh Bank ABC. Dengan formulasi strategi menggunakan pendekatan David (2011) diharapkan didapatkan alternatif strategi yang berkelanjutan untuk pengembangan digital banking Bank ABC. AHP digunakan dengan harapan didapatkan keterhubungan antara sasaran digital Bank ABC, kompetensi masa depan perbankan digital dan alternatif strategi berkelanjutan Bank ABC. Selain itu, dengan penggunaan AHP diharapkan mendapatkan prioritas pemenuhan kompetensi masa depan dan alternatif strategi.

\section{HASIL}

\section{Laporan Tahunan 2017 Bank ABC: Kualitas, Efisiensi, Digitalisasi}

Memasuki era disrupsi yang ditandai dengan kehadiran industri teknologi finansial, perbankan digital, dan menghadapi situasi ekonomi politik yang sangat dinamis, Kualitas, Efisiensi, dan Digitalisasi menjadi pilihan kata kunci yang ditetapkan Bank ABC untuk memacu pertumbuhan kinerja baik untuk jangka pendek maupun jangka panjang. Perseroan meyakini tiga elemen tersebut merupakan pilihan strategi yang harus diimplementasikan untuk mengantisipasi iklim bisnis perbankan yang mulai memasuki masa maturity. Digital difokuskan pada pengembangan digitalisasi bisnis proses internal, pengembangan produk dan layanan yang relevan dengan kebutuhan pasar. Hal ini tepat untuk era disrupsi saat ini, digitalisasi tidak hanya diarahkan kepada pelanggan, akan tetapi termasuk digitalisasi internal. Menurut Bareisis dan Latimore (2014), digital dalam perbankan adalah tentang memberikan pengalaman merek lembaga keuangan yang dapat disesuaikan namun konsisten kepada pelanggan melalui semua saluran dan titik interaksi yang didukung oleh analitik dan otomatisasi, dan membutuhkan perubahan dalam produk dan layanan, teknologi informasi, organisasi dan SDM untuk mewujudkan nilai ekonomi yang dapat didemonstrasikan dan berkelanjutan.

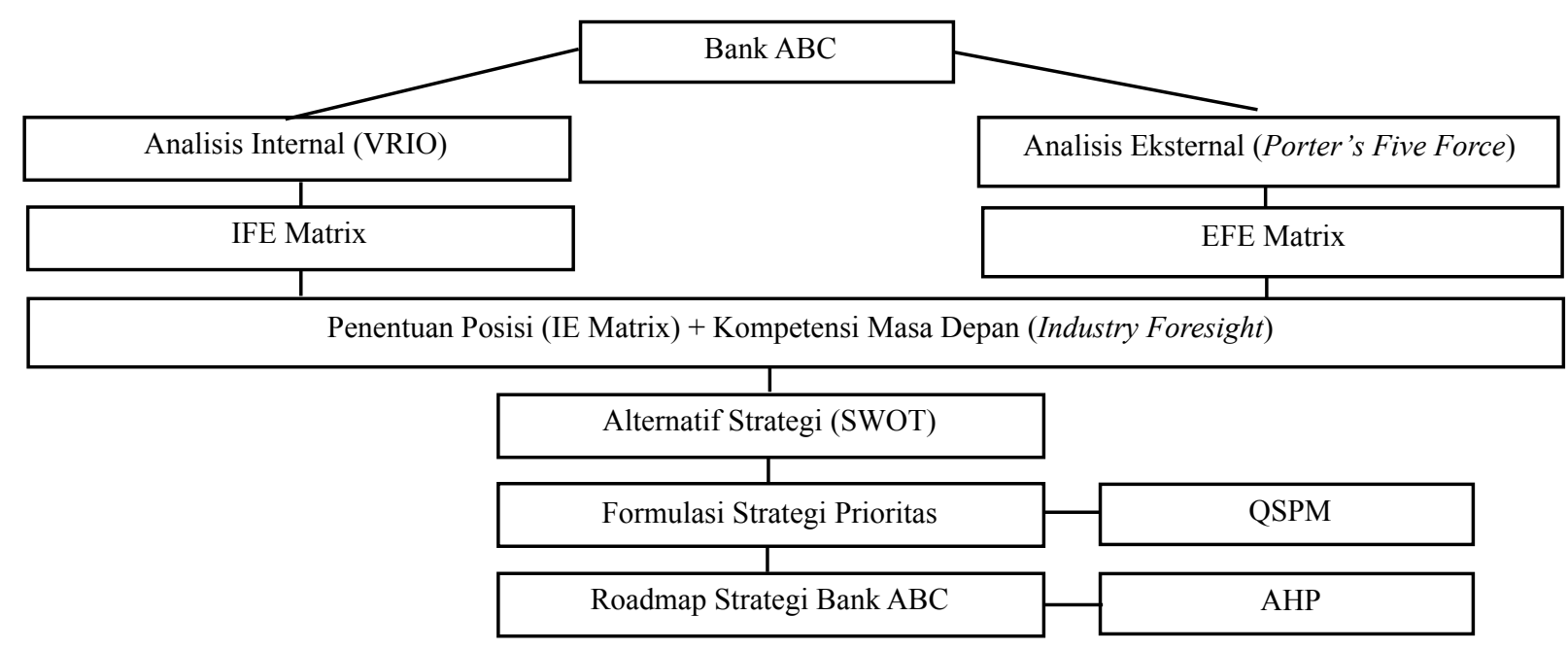

Gambar 1. Kerangka pemikiran penelitian 


\section{Identifikasi Faktor Lingkungan Internal dan Eksternal}

Hasil identifikasi menggunakan pendekatan analisis VRIO menunjukkan sejumlah faktor lingkungan internal perusahaan. Berdasarkan diskusi dan peratingan oleh responden yang merupakan pengambil keputusan, ditentukan masing-masing lima peubah faktor lingkungan internal yang paling penting dan berpengaruh. Peubah tersebut merupakan kekuatan dan kelemahan bagi Bank ABC (Tabel 1).

Hasil identifikasi menggunakan pendekatan analisis Porter's Five Force menunjukkan sejumlah faktor lingkungan eksternal perusahaan. Berdasarkan diskusi dan peratingan oleh responden yang merupakan pengambil keputusan, ditentukan masing-masing lima peubah faktor lingkungan eksternal yang paling penting dan berpengaruh. Peubah tersebut merupakan peluang dan ancaman bagi Bank ABC (Tabel 2).

\section{Tahap Pemasukan (Input Stage)}

Dalam evaluasi faktor internal dan eksternal dengan angka bobot merupakan hasil rataan geometrik pendapat lima orang ahli dengan menggunakan metode perbandingan matriks berpasangan. Demikian juga rating diperoleh dari modus pendapat lima orang ahli. Hasil evaluasi faktor internal dan eksternal disajikan dalam Tabel 3 dan Tabel 4.

Tabel 1. Daftar kekuatan dan kelemahan

\begin{tabular}{ll}
\hline Kekuatan & Kelemahan \\
\hline Bank telah memiliki strategi pemanfaatan Big Data & $\begin{array}{l}\text { Pemanfaatan data eksternal dan } \text { unstructured data untuk } \\
\text { analisis customer behavior belum dilakukan. }\end{array}$ \\
$\begin{array}{l}\text { Platform. } \\
\text { Pemimpin pasar dalam bisnis pembayaran public utilities. }\end{array}$ & $\begin{array}{l}\text { Pelanggan hanya memiliki akses perbankan, tidak memiliki } \\
\text { akses keuangan lainnya (asuransi, financial advice, leasing). }\end{array}$ \\
$\begin{array}{l}\text { Bank sedang melakukan migrasi Core Banking System dari } \\
\text { close system ke open system. }\end{array}$ & $\begin{array}{l}\text { Belum memiliki pandangan yang jelas bagaimana } \\
\text { penerjemahan transformasi digital ke dalam nilai ekonomi. }\end{array}$ \\
Bank memiliki inkubasi Fintech/Startup. & $\begin{array}{l}\text { Bank belum memiliki karyawan dengan kompetensi khusus } \\
\text { digital seperti UX Designer, Data Scientist, Social Media }\end{array}$ \\
& $\begin{array}{l}\text { Marketing, SCRUM Master, dll. } \\
\text { Mayoritas pengembangan Aplikasi TI dilakukan secara }\end{array}$ \\
Pengembangan produk e-channel masih menggunakan pola \\
inhouse.
\end{tabular}

Tabel 2. Daftar peluang dan ancaman

\begin{tabular}{|c|c|}
\hline Peluang & Ancaman \\
\hline $\begin{array}{l}\text { Pemasok layanan seperti PLN, Pertamina, Universitas, } \\
\text { PLN, DJP, Pertamina, BPJS Ketenagakerjaan sudah } \\
\text { terhubung langsung dengan Bank ABC. }\end{array}$ & $\begin{array}{l}\text { Switching cost yang dikeluarkan konsumen kecil, } \\
\text { konsumen dapat menikmati layanan perbankan bersamaan } \\
\text { dengan kegiatan konsumen pada platform aplikasi seperti } \\
\text { transportasi online dan marketplace tanpa harus beralih ke } \\
\text { channel perbankan. }\end{array}$ \\
\hline $\begin{array}{l}\text { Kebijakan pemerintah cukup membantu dalam menghadang } \\
\text { banyaknya pendatang baru yang melakukan coba-coba. }\end{array}$ & $\begin{array}{l}\text { Dengan regulasi yang belum ketat, Startup dan Fintech } \\
\text { lebih leluasa melakukan inovasi produk. }\end{array}$ \\
\hline $\begin{array}{l}\text { Persaingan perolehan bahan baku (biller, payment gateway, } \\
\text { kerjasama host to host) tidak terlalu berpengaruh terhadap } \\
\text { perusahaan karena Bank ABC sudah memiliki hubungan } \\
\text { yang kuat dengan penyedia bahan baku. }\end{array}$ & $\begin{array}{l}\text { Dengan model pemasaran digital yang lebih efektif dan } \\
\text { efisien dibandingkan dengan pemasaran offline, Startup } \\
\text { dan Fintech sangat aktif dalam pemasaran dan menjadi } \\
\text { ancaman Bank ABC. }\end{array}$ \\
\hline $\begin{array}{l}\text { Konsumen bukan setingkat korporasi dan tidak adanya } \\
\text { dominasi konsumen. }\end{array}$ & $\begin{array}{l}\text { Kemampuan memanfaatkan pelanggan yang kecanduan } \\
\text { dengan gadget, melalui big data analytics dan push } \\
\text { notification, maka pelanggan menjadi lebih personal dengan } \\
\text { platform aplikasi pendatang baru tersebut, dan menciptakan } \\
\text { loyalitas yang tinggi dari pelanggan. }\end{array}$ \\
\hline $\begin{array}{l}\text { Kebijakan pemerintah tentang kecukupan modal untuk } \\
\text { memiliki izin penyelenggara uang elektronik dan pinjaman } \\
\text { online. }\end{array}$ & $\begin{array}{l}\text { Khusus untuk rekrutmen pegawai dengan kapabilitas digital } \\
\text { seperti digital marketing, mobile programmer, data scientist } \\
\text { menjadi ancaman, karena Startup dan Fintech dapat } \\
\text { memberikan penghasilan yang lebih baik dan kebebasan } \\
\text { dalam bekerja. }\end{array}$ \\
\hline
\end{tabular}




\begin{tabular}{|c|c|c|c|c|}
\hline & Faktor Internal & Bobot & Rating & Skor \\
\hline \multicolumn{5}{|c|}{ Kekuatan } \\
\hline S1 & Bank telah memiliki strategi pemanfaatan Big Data Platform. & 0,080 & 3,00 & 0,240 \\
\hline S2 & Pemimpin pasar dalam bisnis pembayaran public utilities. & 0,079 & 3,00 & 0,237 \\
\hline S3 & $\begin{array}{l}\text { Bank sedang melakukan migrasi Core Banking System dari close system ke open } \\
\text { system. }\end{array}$ & 0,100 & 4,00 & 0,400 \\
\hline S4 & Bank memiliki inkubasi Fintech/Startup. & 0,101 & 4,00 & 0,404 \\
\hline S5 & Mayoritas pengembangan Aplikasi TI dilakukan Inhouse. & 0,080 & 3,00 & 0,240 \\
\hline \multicolumn{5}{|c|}{ Kelemahan } \\
\hline W1 & $\begin{array}{l}\text { Pemanfaatan data eksternal dan unstructured data untuk analisis customer behavior } \\
\text { belum dilakukan. }\end{array}$ & 0,092 & 2,00 & 0,184 \\
\hline W2 & $\begin{array}{l}\text { Pelanggan hanya memiliki akses perbankan, tidak memiliki akses keuangan lainnya } \\
\text { (asuransi, financial advice, leasing). }\end{array}$ & 0,108 & 2,00 & 0,216 \\
\hline W3 & $\begin{array}{l}\text { Belum memiliki pandangan yang jelas bagaimana penerjemahan transformasi digital ke } \\
\text { dalam nilai ekonomi. }\end{array}$ & 0,148 & 1,00 & 0,148 \\
\hline W4 & $\begin{array}{l}\text { Bank belum memiliki karyawan dengan kompetensi khusus digital seperti UX Designer, } \\
\text { Data Scientist, Social Media Marketing, SCRUM Master, dll. }\end{array}$ & 0,108 & 2,00 & 0,216 \\
\hline \multirow[t]{2}{*}{ W5 } & $\begin{array}{l}\text { Pengembangan produk e-channel masih menggunakan pola Waterfall, belum adopsi } \\
\text { Agile Development. }\end{array}$ & 0,104 & 2,00 & 0,209 \\
\hline & Total & 1,000 & & 2,493 \\
\hline
\end{tabular}

Tabel 4. Evaluasi faktor eksternal

\begin{tabular}{ccc}
\hline Faktor Eksternal & Bobot Rating Skor \\
\hline Peluang &
\end{tabular}

O1 Pemasok eksisting seperti telekomunikasi, listrik, PDAM, biasanya hanya disediakan oleh

$0,113 \quad 4,00 \quad 0,453$ satu atau dua payment gateway. Pemasok layanan seperti PLN, Pertamina, Universitas, PLN, DJP, Pertamina, BPJS Ketenagakerjaan sudah terhubung langsung dengan Bank ABC.

O2 Kebijakan pemerintah cukup membantu dalam menghadang banyaknya pendatang baru yang melakukan coba-coba.

O3 Persaingan perolehan bahan baku (biller, payment gateway, kerjasama host to host) tidak terlalu berpengaruh terhadap perusahaan karena Bank ABC sudah memiliki hubungan yang kuat dengan penyedia bahan baku.

O4 Konsumen bukan setingkat korporasi dan tidak adanya dominasi konsumen.

$\begin{array}{lll}0,079 & 3,00 & 0,237 \\ 0,102 & 4,00 & 0,409 \\ & & \\ 0,070 & 3,00 & 0,210 \\ 0,086 & 3,00 & 0,257\end{array}$

O5 Kebijakan pemerintah tentang kecukupan modal untuk memiliki izin penyelenggara uang elektronik dan pinjaman online.

\section{Ancaman}

T1 Switching cost yang dikeluarkan konsumen kecil, konsumen dapat menikmati layanan perbankan bersamaan dengan kegiatan konsumen pada platform aplikasi seperti transportasi online dan marketplace tanpa harus beralih ke channel perbankan.

T2 Dengan regulasi yang belum ketat, Startup dan Fintech lebih leluasa melakukan inovasi produk.

T3 Dengan model pemasaran digital yang lebih efektif dan efisien dibandingkan dengan pemasaran offline, Startup dan Fintech sangat aktif dalam pemasaran dan menjadi ancaman Bank ABC.

T4 Kemampuan memanfaatkan pelanggan yang kecanduan dengan gadget, melalui big data analytics dan push notification, maka pelanggan menjadi lebih personal dengan platform aplikasi pendatang baru tersebut, dan menciptakan loyalitas yang tinggi dari pelanggan.

T5 Khusus untuk rekrutmen pegawai dengan kapabilitas digital seperti digital marketing, mobile programmer, data scientist menjadi ancaman, karena Startup dan Fintech dapat memberikan penghasilan yang lebih baik dan kebebasan dalam bekerja. 
Total skor evaluasi faktor internal adalah 2,493. Hasil evaluasi faktor internal menunjukkan bahwa secara internal perusahaan berada dalam posisi dibawah rataan $(2,5)$ dalam menggunakan kekuatan dan meminimalkan kelemahan. Total skor evaluasi faktor eksternal adalah 2,322, dibawah rataan $(2,5)$. Hasil evaluasi faktor eksternal menunjukkan perusahaan belum dapat memanfaatkan peluang dan tidak dapat menghindari ancaman.

\section{Tahap Pencocokan (Matching Stage)}

Internal-external (IE) matrix merupakan penggabungan informasi dari evaluasi faktor internal (IFE) dan faktor eksternal (EFE). Skor IFE adalah 2,493 dan skor EFE adalah 2,322. Hasil pemaduan skor IFE dan EFE dalam matriks IE menunjukkan posisi perusahaan berada dalam sel V. Menurut David (2011) sel V merupakan posisi perusahaan harus dijaga dan dipertahankan melalui strategi penetrasi pasar dan pengembangan produk.

\section{Kompetensi Masa Depan}

Hasil identifikasi menggunakan pendekatan analisis VRIO menunjukkan 13 kompetensi inti eksisting sebagai acuan dalam mengembangkan kompetensi masa depan Bank ABC. Mengacu pada teori dan penelitian yang berkaitan, maka direkomendasikan 3 kompetensi masa depan sebagai pengembangan dari 13 kompetensi inti eksisting sebagaimana ditunjukan pada Tabel 5.

\section{Digitalisasi Dua Arah}

Menurut Falato et al. (2013), sebagian besar bank telah berfokus pada transformasi customer experience menggunakan teknologi digital (mobile). Dengan melakukan itu, mereka berpotensi kehilangan peluang lebih besar yang mereka miliki, tepat di halaman belakang mereka - digitalisasi operasional bank. Kompetensi digital yang dilakukan Bank ABC masih seputar customer experience dengan memiliki tabungan digital, pembukaan tabungan dan branchless banking. Rencana migrasi Core Banking System (CBS) dapat dimanfaatkan Bank $\mathrm{ABC}$ untuk digitalisasi middleand-back-office. Migrasi CBS adalah tindak lanjut dari Kajian Migrasi CBS pada tahun 2017-2018 dengan salah satu observasi signifikan yang ditemukan dalam kajian adalah banyak proses bisnis terkait produk yang masih dilakukan secara manual.

\section{Open Banking}

Menurut Cohen (2014), strategi delivery perbankan digital harus mencakup integrasi multichannel, yang harus siap untuk mendistribusikan transaksi bank, produk dan layanan ke perangkat apa pun melalui mekanisme pengiriman apa pun kepada nasabah, baik konsumen, bisnis, atau pihak ketiga terkait, aplikasi pihak ketiga, atau situs pihak ketiga. Omarini (2017), dalam penelitiannya menyarankan kepada bank agar mempertimbangkan pergerakannya dari menghadapi persaingan baru dengan membangun bentuk baru kolaborasi. Pengembang Fintech membutuhkan bank untuk hal-hal seperti berikut ini: akses ke simpanan konsumen atau data akun terkait; akses ke sistem pembayaran; originasi kredit; atau manajemen kepatuhan. Menurut Tan et al. (2016), SOA dan komputasi service telah melampaui teknologi interoperasi. Web API (Application Programming Interface) REST (Representational State Transfer) telah menggantikan SOAP (Simple Object Access Protocol) yang dilayani karena dua alasan: pertama, antarmuka REST create, read, update, dan delete (CRUD) sangat meningkatkan penggunaan; kedua, JSON (JavaScript Object Nation) dengan REST membuat muatan komunikasi lebih sederhana dan lebih mudah dipahami, dibandingkan dengan XML (eXtensible Markup Language) dengan SOAP. Mulai 2006 Google meninggalkan SOAP dan hanya menggunakan REST di API pencariannya. Sementara SOAP/WSDL masih populer di banyak sistem perusahaan seperti Bank ABC, Web API REST meresap dalam aplikasi Web, seluler, cloud, dan Internet of Things (IoT).

Analitik dan Otomasi Digital

Rencana pemanfaatan Big Data sebagai kekuatan dan belum dilakukannya pemanfaatan data eksternal sebagai kelemahan menunjukan bahwa pemanfaatan Big Data sudah dianggap strategi yang penting untuk Bank ABC. Menurut penelitian yang dilakukan Hassani et al. (2018), eksplorasi alat big data analytic canggih seperti teknik Data Mining (DM) adalah kunci untuk sektor perbankan, yang bertujuan untuk mengungkapkan informasi berharga dari volume data yang luar biasa dan mencapai manajemen strategis dan kepuasan pelanggan yang lebih baik. Menurut Bareisis dan Latimore (2014), salah satu area kunci otomasi adalah "Natural Best Friend" atau artificial intelligence (AI) yang digunakan untuk mengotomatiskan komunikasi pelanggan baik lisan maupun tulisan, baik masukan (OCR, analisis suara) dan luaran (suara/penulisan teks 
otomatis). Departemen TI Bank ABC telah memiliki Chatbot (produk AI) dan dapat dikembangkan untuk melayani nasabah maupun non nasabah.

Sebagai perusahaan yang berbisnis kepercayaan dan highly regulated serta rentan terhadap serangan keamanan, untuk menjaga kualitas layanan TI dan keamanan informasi, dua kompetensi eksisting pada bidang Tata Kelola TI yaitu sertifikasi ISO20000 (Information Technology Service Management) dan ISO27001 (Information Security Management System) adalah mutlak harus dimiliki. Pada perbankan digital, internet banking merupakan bagian penting yang dapat menawarkan solusi dalam bertransaksi. Pada sisi lain manajemen perlu meningkatkan kepercayaan kepada konsumen dengan memastikan keamanan di setiap aktifitas yang dilakukannya (Twum dan Ahenkora 2012). Menurut Ali dan Soomro (2014), organisasi dapat menggunakan IT Infrastructure Library (ISO2000) dan MOF (Microsoft Operations Framework) untuk mendefinisikan proses, menggunakan audit TI COBIT, tolok ukur tata kelola TI dan menggunakan ISO 27002 untuk mengatasi masalah keamanan untuk mengurangi kemungkinan risiko. Hal ini akan mengarah pada manajemen layanan TI yang lebih baik dengan tata kelola TI yang kuat dan informasi yang aman dalam organisasi.

\section{Matriks SWOT dan Tahap Keputusan (Decision Stage)}

Hasil perumusan strategi menggunakan matriks SWOT menghasilkan 11 (sebelas) strategi. Dengan menggunakan QSPM (Tabel 6), terpilihnya strategi membangun/re-engineering produk bank yang dapat dipasarkan baik oleh Bank ABC maupun Fintech/ Startup rekanan untuk segmen yang menjadi sasaran Fintech dan/atau Startup (5,84) sebagai strategi prioritas pertama dibandingkan strategi lainnya, sesuai dengan hasil analisis matriks Internal-External (IE) yang memposisikan perusahaan harus dijaga dan dipertahankan melalui strategi pengembangan produk dan penetrasi pasar.

Tabel 5. Kompetensi Masa Depan

\begin{tabular}{|c|c|c|}
\hline Kompetensi Inti Eksisting & Implikasi Kompetitif & Kelemahan/Kekuatan \\
\hline \multicolumn{3}{|l|}{ Kompetensi Masa Depan: Digitalisasi Dua Arah } \\
\hline Bank telah memiliki layanan Branchless Banking & $\begin{array}{l}\text { Keunggulan Kompetitif } \\
\text { Sementara }\end{array}$ & Kekuatan dan Kompetensi Khusus \\
\hline Bank telah memiliki tabungan digital & $\begin{array}{l}\text { Keunggulan Kompetitif } \\
\text { Sementara }\end{array}$ & Kekuatan dan Kompetensi Khusus \\
\hline $\begin{array}{l}\text { Bank sudah memiliki aplikasi digital untuk } \\
\text { pembukaan rekening tabungan }\end{array}$ & $\begin{array}{l}\text { Keunggulan Kompetitif } \\
\text { Sementara }\end{array}$ & Kekuatan dan Kompetensi Khusus \\
\hline $\begin{array}{l}\text { Mayoritas pengembangan Aplikasi TI dilakukan } \\
\text { secara Inhouse }\end{array}$ & $\begin{array}{l}\text { Keunggulan Kompetitif } \\
\text { Sementara }\end{array}$ & Kekuatan dan Kompetensi Khusus \\
\hline $\begin{array}{l}\text { Bank sedang melakukan migrasi Core Banking } \\
\text { System dari close system ke open system }\end{array}$ & $\begin{array}{l}\text { Keunggulan Kompetitif } \\
\text { Berkelanjutan }\end{array}$ & $\begin{array}{c}\text { Kekuatan dan Kompetensi Khusus } \\
\text { Jangka Panjang }\end{array}$ \\
\hline \multicolumn{3}{|l|}{ Kompetensi Masa Depan: Open Banking } \\
\hline Memiliki channel yang beragam & $\begin{array}{l}\text { Keunggulan Kompetitif } \\
\text { Berkelanjutan }\end{array}$ & $\begin{array}{c}\text { Kekuatan dan Kompetensi Khusus } \\
\text { Jangka Panjang }\end{array}$ \\
\hline $\begin{array}{l}\text { Bank sudah terhubung realtime online dengan } \\
\text { Disdukcapil }\end{array}$ & $\begin{array}{l}\text { Keunggulan Kompetitif } \\
\text { Berkelanjutan }\end{array}$ & $\begin{array}{c}\text { Kekuatan dan Kompetensi Khusus } \\
\text { Jangka Panjang }\end{array}$ \\
\hline $\begin{array}{l}\text { Pemimpin pasar dalam bisnis pembayaran public } \\
\text { utilities }\end{array}$ & $\begin{array}{l}\text { Keunggulan Kompetitif } \\
\text { Sementara }\end{array}$ & Kekuatan dan Kompetensi Khusus \\
\hline Bank memiliki inkubasi Fintech/Startup & $\begin{array}{l}\text { Keunggulan Kompetitif } \\
\text { Berkelanjutan }\end{array}$ & $\begin{array}{c}\text { Kekuatan dan Kompetensi Khusus } \\
\text { Jangka Panjang }\end{array}$ \\
\hline \multicolumn{3}{|c|}{ Kompetensi Masa Depan: Analitik dan Otomasi Digital } \\
\hline $\begin{array}{l}\text { Departemen IT Bank memiliki Chatbot untuk } \\
\text { melayani pelanggan internal }\end{array}$ & $\begin{array}{l}\text { Keunggulan Kompetitif } \\
\text { Berkelanjutan }\end{array}$ & $\begin{array}{c}\text { Kekuatan dan Kompetensi Khusus } \\
\text { Jangka Panjang }\end{array}$ \\
\hline $\begin{array}{l}\text { Bank telah memiliki strategi pemanfaatan Big } \\
\text { Data Platform }\end{array}$ & $\begin{array}{l}\text { Keunggulan Kompetitif } \\
\text { Sementara }\end{array}$ & Kekuatan dan Kompetensi Khusus \\
\hline
\end{tabular}




\begin{tabular}{|c|c|}
\hline Alternatif Strategi & TAS \\
\hline $\begin{array}{l}\text { Membangun/reengineering produk bank yang dapat dipasarkan baik oleh Bank ABC maupun Fintech dan/atau } \\
\text { Startup rekanan untuk segmen yang menjadi sasaran Fintech dan/atau Startup. }\end{array}$ & 5,84 \\
\hline $\begin{array}{l}\text { Melaksanakan program transformasi menuju perbankan digital secara bank wide untuk memiliki kecepatan, } \\
\text { tingkat efisiensi dan kelincahan seperti Fintech/Startup. }\end{array}$ & 5,68 \\
\hline $\begin{array}{l}\text { Melakukan kerjasama dengan Fintech dan/atau Startup dalam mengembangkan produk, pemasaran dan } \\
\text { pemanfaatan teknologi yang terbarukan. }\end{array}$ & 5,29 \\
\hline $\begin{array}{l}\text { Melakukan perampingan dan digitalisasi sistem dan prosedur bank yang konvensional dengan tujuan kelincahan, } \\
\text { efektifitas dan efisiensi dengan pemanfaatan teknologi yang digunakan Fintech/Startup. }\end{array}$ & 4,79 \\
\hline $\begin{array}{l}\text { Melakukan kerjasama penjualan produk host to host Bank ABC dengan Fintech/Startup yang tergabung dalam } \\
\text { program inkubasi Bank ABC. }\end{array}$ & 4,77 \\
\hline $\begin{array}{l}\text { Melakukan penyesuaian kebijakan dan prosedur pengembangan aplikasi tidak terbatas pada e-channel dari } \\
\text { waterfall menjadi agile development. }\end{array}$ & 4,18 \\
\hline $\begin{array}{l}\text { Melakukan pemanfaatan media social analysis dan FGD dengan nasabah eksisting untuk melakukan inovasi } \\
\text { produk keuangan baik produk bank maupun non bank. }\end{array}$ & 3,99 \\
\hline $\begin{array}{l}\text { Implementasi Big Data Platform untuk membangun engagement dengan nasabah (personalization) dan } \\
\text { menghasilkan pemasaran yang lebih efektif dan efisien. }\end{array}$ & 3,94 \\
\hline $\begin{array}{l}\text { Melakukan pemanfaatan model pemasaran digital untuk pemasaran produk dan/atau layanan bank melalui media } \\
\text { digital yang digemari masyarakat seperti Youtube, Instagram dan Facebook. }\end{array}$ & 3,78 \\
\hline Menetapkan kebijakan bisnis dan operasional di cabang dalam mengahadapi nasabah yang digital savvy. & 3,61 \\
\hline $\begin{array}{l}\text { Reengineering kebijakan pemenuhan SDM dengan kapabilitas digital, tidak terbatas pada training, remunerasi } \\
\text { dan retention untuk karyawan lama. }\end{array}$ & 2,93 \\
\hline
\end{tabular}

Berbeda dengan penelitian yang dilakukan oleh Muluka et al. (2015), hasil pada penelitian ini digital banking tidak terfokus pada aksesibilitas dari nasabah (front-end) tetapi termasuk back-end dan middleend. Menurut Muluka et al. (2015), ada peningkatan aksesibilitas perbankan digital yang didukung oleh peningkatan jumlah ATM, mobile dan internet banking. Bank telah meningkatkan agensi perbankan untuk memanfaatkan basis pelanggan yang tumbuh sehingga meningkatkan aksesibilitas mereka. Berbeda dengan hasil penelitian Syed dan Raza (2011) yang masih berfokus pada keterampilan pengguna sebagai pendorong bagi bank untuk menyusun strategi teknologi mereka, selain faktor pengguna, berdasarkan alternatif strategi yang dihasilkan pada penelitian ini, yang menjadi pendorong dalam menyusun strategi adalah pengembangan produk terkini, proses bisnis internal; budaya perusahaan; Fintech dan Startup; dan big data and social media analysis. Berikut ini adalah pengelompokan alternatif strategi berdasarkan faktor pendorong: Reengineering Produk: alternatif strategi 1; Program Transformasi: alternatif strategi 2, 10 dan 11; Kerjasama Fintech/Startup: alternatif strategi 3 dan 5; Digitalisasi Sistem dan Prosedur (Sisdur): alternatif strategi 4 dan 6; dan Media Social Analysis: alternatif strategi 7,8 dan 9 .

\section{Road Map Implementasi Strategi}

Untuk mencapai sasaran digitalisasi Bank $A B C$, penulis merekomendasikan road map implementasi strategi digital banking Bank $\mathrm{ABC}$ berdasarkan prioritas dan kompetensi masa depan menggunakan metode AHP. Sebagai langkah awal memasuki era digital, Bank ABC memberikan tugas dan tanggung jawab perbankan digital kepada Divisi Perbankan Digital dan Transaksi (DPDT). Pada AHP ditentukan hanya 1 aktor, yaitu DPDT. Kriteria yang menjadi pilihan adalah kompetensi inti masa depan, dan sebagai alternatif strategi adalah 5 kelompok strategi hasil analisis SWOT-QSPM. Hasil dari pengolahan horizontal dan vertikal menggunakan AHP yang merupakan penggabungan penilaian pakar ahli seperti pada Gambar 2 dapat dijadikan sebagai informasi dan bahan pertimbangan dalam tercapainya sasaran Bank ABC.

Berdasarkan hasil sintesis penilaian bobot alternatif, alternatif strategi utama adalah reengineering produk bank yang dapat dipasarkan baik oleh Bank ABC maupun Fintech dan/atau Startup untuk segmen konsumen Fintech dan/atau Startup $(0,245)$. Pemilihan alternatif strategi utama sesuai dengan hasil analisis Internal-External (IE) yang memposisikan perusahaan harus dijaga dan dipertahankan melalui strategi penetrasi pasar dan pengembangan produk. Pada 
level kriteria, kompetensi masa depan utama adalah Digitalisasi Dua Arah $(0,412)$.

\section{Implikasi Manajerial}

Para pemangku kepentingan yang menjadi responden pada penelitian ini memahami bahwa perbankan digital bukan hanya layanan, tetapi bank secara organisasai harus bekerja secara digital. Bank ABC perlu memiliki Divisi yang khusus memiliki tugas dan tanggung jawab perbankan digital dengan cakupan bank wide, tidak bergabung dengan Direktorat Bisnis. Divisi ini dapat berupa Satuan Kerja sementara yang akan memimpin seluruh Divisi lintas Direktorat dalam digitalisasi Bank $\mathrm{ABC}$.

Dengan didapatkannya prioritas setiap level hierarki hasil pengolahan AHP, Bank $\mathrm{ABC}$ juga dapat merencanakan strategi investasi biaya yang lebih efisien dan tepat sasaran sehingga didapatkan hasil yang optimal sesuai dengan kondisi keuangan perusahaan. Bank ABC dapat melakukan implementasi dengan jangka panjang apabila terdapat keterbatasan resource. Bank ABC dapat fokus untuk implementasi Digitalisasi Dua Arah pada tahun pertama sebagai quick win, dan pada saat yang bersamaan Bank ABC dapat melakukan proof of concept (poc) Open Banking dan Analitik \& Otomasi Digital dalam rangka perencanaan untuk diimplementasikan pada tahun berikutnya.

\section{KESIMPULAN DAN SARAN}

\section{Kesimpulan}

Teridentifikasi 13 kompetensi inti Bank ABC dengan implikasi keunggulan kompetitif baik sementara maupun berkelanjutan dengan menggunakan analisis VRIO. Hasil analisis industry foresight, direkomendasikan 3 kompetensi masa depan untuk dimiliki Bank $\mathrm{ABC}$ dalam pengembangan digital banking Bank $\mathrm{ABC}$, yaitu Digitalisasi Dua Arah, Open Banking dan Analitik \& Otomasi Digital. Dirumuskan 11 alternatif strategi yang berkelanjutan dalam mengembangkan digital banking Bank $\mathrm{ABC}$ dengan menggunakan matriks SWOT dan QSPM. Pengelompokan alternatif strategi berdasarkan faktor pendorong adalah sebagai berikut: Reengineering Produk, Program Transformasi, Kerjasama Fintech/ Startup, Digitalisasi Sistem dan Prosedur (Sisdur), dan Media Social Analysis. Direkomendasikan road map implementasi strategi digital banking Bank ABC dengan menggunakan AHP dan alat bantu software Expert Choice. Alternatif strategi utama adalah reengineering produk bank yang dapat dipasarkan baik oleh Bank ABC maupun Fintech dan/atau Startup untuk segmen konsumen Fintech dan/atau Startup. Pada level kriteria, kompetensi masa depan utama adalah Digitalisasi Dua Arah.

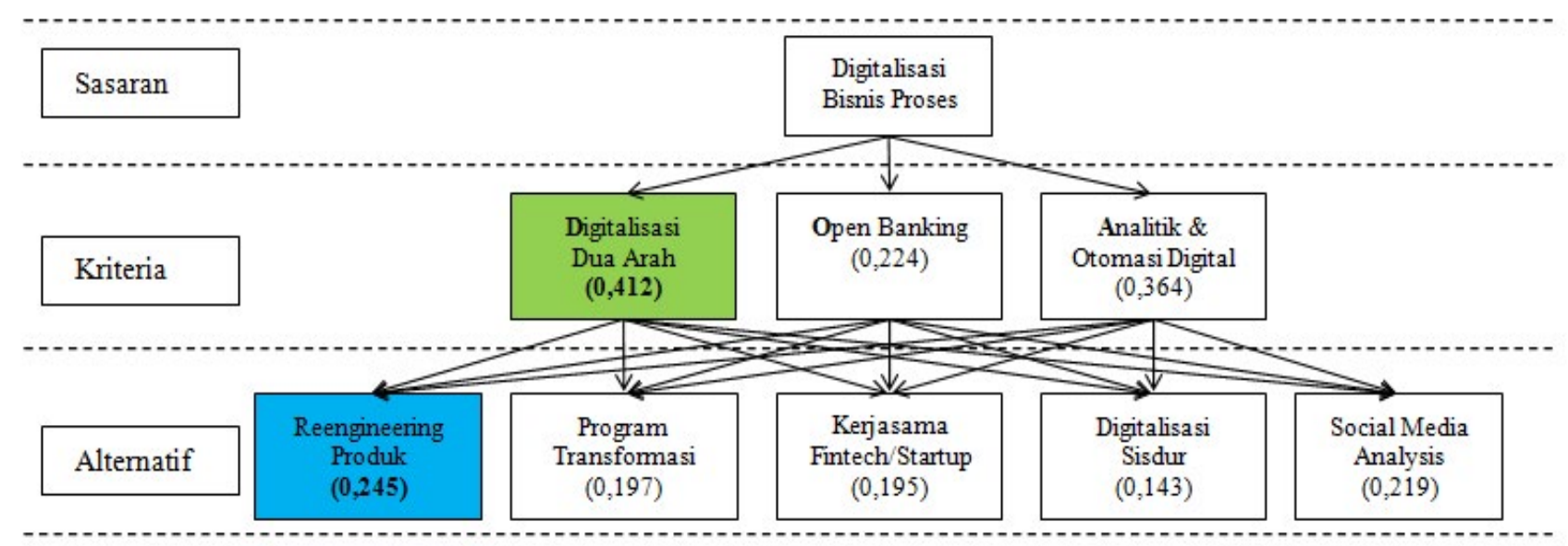

Gambar 2. Hierarki dan bobot pengolahan AHP 


\section{Saran}

Penelitian ini masih memiliki kekurangan, diantaranya adalah tidak adanya aktor pada AHP. Sehubungan dengan tugas dan tanggung jawab digital saat ini diberikan kepada satu Divisi, sementara strategi digitalisasi yang dihasilkan adalah berbagai disiplin ilmu, maka disarankan untuk penelitian selanjutnya dilakukan dengan sudut pandang bank wide, sehingga dapat dihasilkan alternatif strategi untuk Divisi sesuai disiplin ilmunya masing-masing. Dengan demikian, pada penelitian selanjutnya dapat ditentukan aktor pada AHP dengan jumlah lebih dari satu.

Ketiga kompetensi inti masa depan yang telah dirumuskan pada penelitian ini adalah kompetensi yang telah dimiliki oleh Fintech dan/atau Startup. Kompetensi Fintech dan/atau Startup yang belum termasuk adalah pemanfaatan cloud computing. Dengan keterbatasan regulasi mengenai cloud computing, penelitian lanjutan terhadap cloud computing untuk perbankan akan melengkapi hasil penelitian ini dalam inovasi berbasis Fintech pada perbankan.

\section{DAFTAR PUSTAKA}

Agha S, Alrubaiee L, Jamhour M. 2012. Effect of core competence on competitive advantage and organizational performance. International Journal of Business and Management 7(1):192204.

Agustina A. 2018. Analisis digital mastery sebagai sumber keunggulan bersaing Bank BTPN di industri perbankan [tesis]. Yogyakarta: Universitas Gadjah Mada.

Ali A dan Soomro TR. 2014. Bridging gape between ITSM, IT-governance and information security to meet business needs. Research Journal of Applied Sciences, Engineering and Technology 7(23):4906-4909.

Bareisis Z dan Latimore D. 2014. Defining a digital financial institution: what "digital" means in banking. https://www.celent.com/ insights/268657967 [17 Februari 2018].

Budiarto G, Yulianda F, Zulbainarni N. 2018. Strategi sinkronisasi implementasi sistem penjaminan mutu internal (SPMI) dengan ISO 9001 program sarjana IPB. Jurnal Aplikasi Manajemen dan Bisnis 4(2):202-211.

Candra S. 2013. Aplikasi model lima kekuatan Porter pada restoran Drupadi. Binus Business Review 4(1):398-404.

Cardeal N dan Antonio N. 2012. Valuable, rare, inimitable resources and organization (VRIO) resources or valuable, rare, inimitable resources (VRI) capabilities: what leads to competitive advantage? African Journal of Business Management 6(37):10159-10170.

Chrismastianto IAW. 2017. Analisis SWOT implementasi teknologi finansial terhadap kualitas layanan perbankan di Indonesia. Jurnal Ekonomi dan Bisnis 20(1):133-144.

Cohen SB. 2014. Extreme transaction processing: technologies to watch. http://imagesrv.gartner. com/media-products/pdf/SunTec/SunTec-11XCWJRD.pdf. [7 Maret 2018].

Cortet M, Rijks T, Nijland S. 2016. PSD2: the digital transformation accelerator for banks. Journal of Payments Strategy \& Systems 10(1):13-27.

DailySocial.id. 2017. Startup Report 2017. https:// dailysocial.id/report/post/Startup-report-2017. [17 Februari 2018].

David FR. 2011. Strategic Management Concepts and Cases. 13 ${ }^{\text {th }}$ Ed. New Jersey (US): Pearson Education Inc-Prentice Hall.

Falato P, Coumaros J, Buvat J, KVJ Subrahmanyam. 2013. Backing up the digital front: digitizing the banking back office.https://www.capgemini. com/wp-content/uploads/2017/07/backing_up_ the_digital_front25_11_0.pdf. [7 Maret 2018].

Hage SG, Daryanto A, Sahara. 2015. Formulasi strategi untuk meningkatkan daya saing teh putih (studi kasus di Pusat Penelitian Teh dan Kina). Jurnal Penelitian Teh dan Kina 18(2):119-130.

Hassani H, Huang X, Silva E. 2018. Digitalisastion and big data mining in banking. Big Data and Cognitive Computing 2(18):1-13.

Indira S. 2018. BNI digital banking: solusi transformasi perbankan berbasis digital [tesis]. Yogyakarta: Universitas Gadjah Mada.

Mahfud T dan Mulyani Y. 2017. Aplikasi metode QSPM (quantitative strategic planning matrix) (studi kasus: strategi peningkatan mutu lulusan program studi tata boga). Jurnal Sosial Humaniora dan Pendidikan 1(1):66-76.

Maiya R. 2017. How to be a truly Digital Bank. Journal of Digital Banking 1(4):338-348.

Mbama CI dan Ozepue PO. 2018. Digital banking, customer experience and bank financial performance: UK customers' perceptions. International Journal of Bank Marketing 
36(2):230-255.

Muluka KO, Kidombo H, Munyolo W, Oteki EB. 2015. Accessibility of digital banking on customer satisfaction: National Bank of Kenya. IOSR Journal of Business and Management 17(11):4854.

Omarini A. 2017. The digital transformation in banking and the role of Fintechs in the new intermediation scenario. International Journal of Finance, Economics and Trade 1(1):1-6.

OmmaniAR. 2011.Strengths, weaknesses, opportunities and threats (SWOT) analysis for farming system businesses management: case of wheat farmers of Shadervan District, Shoushtar Township, Iran. African Journal of Business Management 5(22):9448-9454.

Presiden Republik Indonesia. 2017. Peraturan Presiden Republik Indonesia Nomor 74 Tahun 2017 tentang Peta Jalan Sistem Perdagangan Nasional Berbasis Elektronik (Road Map E-Commerce) Tahun 2017-2019. Lembaran Negara Republik Indonesia Nomor 176.

Ramadhani P, Baga LM, Sanim B. 2018. Strategi pengembangan perusahaan perdagangan emas wilayah JABODETA (studi kasus PT. XYZ). Jurnal Aplikasi Manajemen dan Bisnis 4(3):420430.

Raymond MLB, Ine M, Iwang G. 2012. Analisis pengembangan usaha pemindangan ikan di Kecamatan Bekasi Barat. Jurnal Perikanan dan Kelautan 3(1):17-24.
Singh S. 2004. Impersonalisation of electronic money: implications for bank marketing. International Journal of Bank Marketing 22(7):504-521.

Skartiningron A. 2017. Transformasi BRI menuju era bank 3.0 melalui optimalisasi BRISAT untuk menjawab era digitalisasi perbankan [tesis]. Yogyakarta: Universitas Gadjah Mada.

Syed SER dan Raza. 2011. Impact of user IT and internet skills on online banking, input to innovative banking strategies. International Journal of Social Sciences and Humanity Studies 3(1):477486.

Tan W, Fan Y, Ghoneim A, Hossain MA, Dustdar S. 2016. From the Service-Oriented Architecture to the WEB API Economy. IEEE Internet Computing 20(4):64-68.

Tornjanski V, Cudanov M, Savoiu G. 2015. A holistic approach to innovation management in banking: a review. Econophysics, Sociophysics \& Other Multidisciplinary Sciences Journal (ESMSJ) 5(2):8-15.

Twum F dan Ahenkora K. 2012. Internet Banking Security Strategy: Securing Customer Trust. Journal of Management and Strategy 3(4):7883.

Wandrial S. 2011. Analisis internal perusahaan (strength \& weakness), menggunakan konsep resource based view of the firm dengan kerangka VRIO. Binus Business Review 2(2):627-637.

Wonglimpiyarat J. 2017. Fintech banking industry: a systemic approach. Journal Emerald Insight 19(6):590-603. 